\title{
Silicon isotope systematics of zircon from various granite types
}

\author{
MARTIN GUITREAU', ABDELMOUHCINE GANNOUN ${ }^{\wedge}$, \\ ZHENGBIN DENG ${ }^{2}$, JOHANNA MARIN-CARBONNE ${ }^{3}$, MARC \\ CHAUSSIDON $^{2}$, FREDERIC MOYNIER ${ }^{2,4}$ \\ Université Clermont Auvergne, Laboratoire Magmas et \\ Volcans, France (martin.guitreau@uca.fr) \\ 2 Université de Paris, Institut de Physique du Globe de Paris, \\ Paris, France \\ Université de Lausanne (UNIL), Lausanne, Switzerland \\ ${ }^{4}$ Institut Universitaire de France, Paris, France
}

Zircon is a mineral extensively used in Earth Sciences as a geochronometer, source tracer for magmatic systems, and witness to continental growth in the detrital record $[1,2]$. Silicon isotopes in bulk-rocks have been shown to discriminate some granite types from others $[3,4]$ and their application to zircon seems promising [5], especially in a perspective of probing the detrital zircon record. Silicon isotope signatures can be controlled by the source, mineralogy, and crystallization history of granitic magmas [6]. Therefore, it is relevant to assess if zircons from distinct granite types exhibit differences such as those visible in bulk-rock data. Moreover, post-crystallization processes that commonly affect zircon (e.g., radiationdamage, metamorphic recrystallization, alteration) are likely to modify its $\mathrm{Si}$ isotope composition, and it is, therefore, also relevant to address this issue.

The present contribution reports new $\mathrm{Si}$ isotope data in zircon measured by LA-MC-ICP-MS and solution MC-ICPMS. Our results show that zircons have $\delta^{30} \mathrm{Si}$ values ranging from $-0.05 \pm 0.15$ and $-0.64 \pm 0.12$ (2SE) for A-type granitoids, from $-0.29 \pm 0.10$ and $-0.83 \pm 0.12$ for Archean TTGs, from $-0.24 \pm 0.12$ and $-0.88 \pm 0.12$ for I-type granitoids, and from $-0.54 \pm 0.14$ and $-0.94 \pm 0.13$ for Stype granitoids. Data for the various granite types investigated here almost entirely overlap and, hence, indicate that $\mathrm{Si}$ isotopes in zircon are not a simple discriminant between granite types. The $\delta^{30} \mathrm{Si}$ variations existing within each type could be a key to constrain the differentiation history of their parent melts and identify source compositions. We will present our conclusions at the conference.

[1] Iizuka et al. (2005) Geology 33, 485-488. [2] Guitreau et al. (2012) EPSL 337-338, 211-223. [3] Savage et al. (2012) GCA 92, 184-202. [4] Deng et al. (2019) Nat. Geosci. 12, 774-778. [5] Trail et al. (2018) PNAS 115, 10287-10292. [6] Poitrasson (2019) RIMG 82, 289-344. 